\title{
Organic viticulture as an important aspect of conserving biodiversity in Crimean agrocenoses
}

\author{
Marina Volkova ${ }^{1, *}$, Elena Matveikina ${ }^{1}$, Jakov Volkov ${ }^{1}$, and Elena Stranisheshevskaya ${ }^{1}$ \\ ${ }^{1}$ Federal State Budget Scientific Institution All-Russian National Research Institute of Viticulture and \\ Winemaking Magarach of the RAS, 31, Kirova str., 298600, Yalta, Republic of Crimea, Russia
}

\begin{abstract}
The current status of the global organic viticulture is discussed. The challenge of conservation of species and landscape biodiversity in the Crimea is actualized. The fauna of mites and other insects in the grape agrocenosis of the South Coast of the Peninsula is reported. Biodiversity of mites and other insects in commercial vineyards at different pesticide loads is shown. The role that wild-growing vegetation in territories adjacent to vineyards plays in the agrolandscape of grape agrocenoses is highlighted. The commonness of species diversity of predatory mites in a vineyard and on its outskirts is revealed. The possibility to rely on natural mechanisms for self-regulation of population numbers of phytophagous mites under conditions of organic viticulture is demonstrated.
\end{abstract}

\section{Introduction}

The Crimean Peninsula is one of the global renowned centers of biological diversity. Special features of its geographical position, relief and climate as well as a relative isolation from the Continent have been conducive to the formation of unique and abundant flora and fauna. Botanical and geographical writings indicate that the Mountainous Crimea, especially the South Coast of the Peninsula, makes part of the Mediterranean floristic area characterized by a highly concentrated species diversity. This is because of the fact that the Mountainous Crimea lies within the extreme eastern limits of the Mediterranean and used to share territories with "the Ancient Mediterranean". Besides, the Crimean flora and fauna can boast representatives of other geographical groups with a high proportion of endemic and relict species. Conservation of species and landscape biodiversity enters as a major ecological challenge on the background of climatic changes and antropogenic load.

Agricultural lands on the South Coast of the Crimea account for $11.5 \%$ of its total area, and the biggest proportion of these goes to commercial vineyards (up to 4 thousand hectares). The majority of vineyards are located in the vicinity of the coastal line, in the recreation zone. At present, the vegetation period on the South Coast of the Crimea sees as many as four insecticide and acaricide treatments against phytophagous mites and other insects and six to eight fungicide treatments to control the major developmental diseases (oidium and mildew). That is why lower pesticide loads and strategy of organic viticulture

\footnotetext{
${ }^{*}$ Corresponding author: frog_marisha@list.ru
} 
on the South Coast of the Crimea are sought for, and this direction of research is urgent and of considerable social, economic and nature-conservative importance.

Transition to organic viticulture highlights, first and foremost, the uncertain control of phytopathogens and agricultural pests since pesticides are no longer allowed within the concept of organic viticulture and the efficiency of authorized biological preparations is unstable. Nevertheless, organic agriculture relying on natural self-regulated processes under conditions of nonuse of pesticides and mineral fertilizers and aiming at ecological product is becoming a trend of the global agroindustrial production [1-4].

The goals of this study were to investigate the acaroentomocomplex fauna in the grape agrocenosis of the South Coast of the Crimea and to actualize the concept of organic viticulture in the Peninsula for conservation of species and landscape biodiversity of grape agrocenoses.

\section{Conditions and Methods of Research}

The geographical position of the South Coast of the Crimea forms a Mediterranean-type climate with rainfalls mostly in autumn and winter, moderately hot and arid summers and mild winters distinguished by often thaws. An increase in the average annual temperature by $0.5^{\circ} \mathrm{C}$ was registered over the period $1990-2014$ versus $1930-2004$ while over the recent 12 years (2006-2014) the increase in the average annual temperature on the South Coast of the Crimea was $1.1^{\circ} \mathrm{C}$ versus the previous decade. On the background of global warming, the sums of active temperatures (warmer than $10^{\circ} \mathrm{C}$ ) went high on an average by $150-200^{\circ} \mathrm{C}$ over the recent quarter of a century versus 1930-2004. December or January on the South Coast of the Crimea has maximum amounts of rainfalls, 58-109 $\mathrm{mm}$ per month in the littoral zone. Most frequently, minimum amounts of rainfals are registered in spring (March-May) or in July and August. At altitudes lower than $200 \mathrm{~m}$, the annual amount of rainfalls in the littoral zone is $680-780 \mathrm{~mm}$. On the whole, the vegetation period in the littoral zone of the South Coast of the Crimea is regarded as arid. The lowest values of hydrothermic coefficient (0.19-0.48) are registered in July. Water requirements of plants in the littoral zone of the South Coast of the Crimea are satisfied only for 48-65\%.

Our study was done in 2006-2019 during the vegetation period (April-October) in commercial vineyards over 20 years old of the South Coast of the Crimea planted to Cabernet Sauvignon, White Muscat and Aligoté. Conventional methods of collection and diagnosis and of ecological-faunistic research were used. Population numbers of mites are given as specimens per registration leaf. Mites and other insects associated with the grape plant to a greater or lesser extent were examined. The population numbers and species diversity of the acaroentomocomplex associated with the grape plant in sites with traditional cultivation envisaging use of pesticides and in "organic sites" without pesticides were analyzed. For statistical data analysis, generally accepted methods were used using statistical programs PAST v. 3.10, Exel, 2007.

\section{Results and Discussion}

Modern statistics indicates a rapid enhancement of the organic vineyard which now accounts for $8 \%$ of the total area of the global organic production, and almost $90 \%$ of them are located in Europe [1, 4]. As predicted by Grand View Research, the organic market may reach $15-20 \%$ of the global agricultural market by 2025 . Over the period 2000-2016, a more than fivefold annual increase in the organic market was registered, from 18 to 90 billion dollars. More than 403000 hectares of organic grapes are grown, constituting 5.7 percent of the world's grape-growing area (7.1 million hectares in 2016, according to 
FAOSTAT) [5]. In Russia, the Law of Organic Products came into effect on January $1^{\text {st }}$ 2020 with the view to promote the domestic organic market.

During transition to organic viticulture, the grower is challenged to control agents of diseases and phytophagous species of mites and other insects when application of pesticides is forbidden and mechanisms for natural self-regulation taking place in natural biocenoses have become impaired following intense chemical protection. Besides, the number of ecological niches in single-crop agrocenoses is not high, leading to a poor diversity of both phytophagous and predatory species, and, in turn, to a less stable triotroph system "plant phytophage - predator", which often gives rise to sudden abundances of individual species. Competition for growing space within one ecological niche can also be found in natural biocenoses with a high total biodiversity, which is another restricting factor for mass development of a individual species. Organic viticulture may also rely on improving the sanitary condition of plants, increasing soil fertility and enhancing the total biodiversity of an agrocenosis. Thus, microbiological preparations and organic fertilizers improve the condition of the upper fertile layer of the soil [6]. Another approach, consisting of green manuring and sowing grass mixtures between the rows, helps regulate the water regime of a vineyard, improve soil fertility and add more ecological niches for arthropoda by attracting pollinators which embrace many parasitic and predatory species. Cancellation of pesticides detrimental to many nontarget species conserves and enhances species diversity of the predatory biota in a vineyard, and migration from surrounding natural biocenoses is also favored [7].

So, it can be seen that organic viticulture results in conservation and enhancement of species and landscape biodiversity in agrocenoses. Besides, modern trends of ecological research in connection with climatic changes and antropogenic load, including organic agriculture, imply formation of a new world outlook, with an emphasis to distribution of such approaches as sustainability of an agroecosystem, agriculture raisonnée, integral pest management (IPM) and precision viticulture [8, 9]. All this envisages minimization of synthetic protection, exclusively for situations of urgent need, and relying on natural selfregulated processes taking place in an agroecosystem.

Massives of small area surrounded by wild-growing vegetation are typical of the Crimean grape agrolandscape, especially on the South Coast of the Peninsula. This entails a "mosaic" pattern of habitats and, consequently, a high species diversity of mites and other insects, including autochthonous predatory fauna biocenotically important for the natural regulation of population numbers of phytophages [7]. A variety of trees, bushes and grasses grow all round the study vineyards on the South Coast of the Crimea: Rosa canina L., Crataegus orientalis_Pall., Rubus canescens DC, Rosmarinus officinalis L., Clematis vitalba L., Vitis sp. (grapevines that have run wild), Malus sp., Prunus divaricatus Ledeb., Fraxinus sp., Ullmus sp., Pistacia sp., Olea europica,L., Aser sp., Arthemisia absenthium L., Rumex sp., Amarantus sp., Cichorium sp., Convolvulus arvensis L., Trifolium pratense L., Hordeum leporinum L., etc. Wild-growing vegetation on the outskirts of vineyards where pesticide load is absent makes an important contribution to conservation and accumulation of a predatory biota and the total species diversity of an agrocenosis [10, 11, $12,13]$. A high faunistic commonness of the complex of predatory mites Phytoseiidae, major regulators of population numbers of phytophagous mites, in vineyards and in bordering natural biotopes with wild-growing grapevines was revealed $\left(K_{j}=0.6-0.8\right)$, which proves that the predators migrate to a vineyard, into the foci where populations of phytophages develop.

The biocenotic triotroph system "plant - phytophage - predator" typical of natural cenoses has been formed and is present in the study agrocenoses too, despite the impoverishment of their plant diversity and effects of chemical treatments. The grape acarocomplex embraces species of various trophic groups. It was established that 
phytophages entering the structure of the acarocomplex were represented by dominating and minor species.

A total of 86 species of mites and other insects from 52 families and 17 orders were identified in the acaroentomocomplex associated with the study grape agrocenosis. 47 species were phytophages and 39 species were predators, including both sedentary species associated with the grape plant (mites and some insects) and actively migrating polyphagous species (the majority of insects). Phytophagous mites were represented by 7 species of 4 families: Tetranychidae - Schizoteranychus (=Eotetranuchus) pruni Oud. (garden spider mite), Tetranychus turkestani Koch (turkestan spider mite), Panonychus ulmi Koch (European red mite); Tenuipalpidae - Hystripalpus (=Brevipalpus) lewisi McG. (citrus flat mite); Eriophyidae - Eriophyes (=Colomerus) vitis Pgst. (grape erineum mite), Calepitrimerus vitis Keifer (grape leaf rust mite); Bryobidae - Briobia redicorzevi Reck (brown fruit mite). Schizotetranychus pruni Oud., a major agricultural pest, has dominated on the South Coast of the Crimea over the recent 14 years. Eriophyes vitis Pgst. is a widespread phytophage though its economical importance is negligible. Tetranychus turkestani Ug. Et Nick., Calepitrimerus vitis Nal. и Hystripalpus lewisi McG. were another minor species.

40 species of 25 families were identified among the study phytophagous insects: Curculionidae (weevils) - Otiorrhynchus asphaltinus Germ., O. aurosparsus Germ.; Bostrichidae (auger beetles) - Amphicerus bimaculatus Ol., Bostrihus capucinus L., Psoa viennensis Hrbst.; Buprestidae (metallic wood-boring beetles) - Agrilus derasofasciatus Lac.; Chrysomelidae (leaf beetles) - Altica ampelophaga Guerin, Labidostomis sp.; Scarabaeidae (scarabs) - Oxythyrea funesta Poda, Cetonia aurata L., Tropinota hirta Poda; Zigaenidae (burnet mothes) - Theresia ampelophaga Bayle.; Heliozelidae - Antispila rivillei Stt.; Tortricidae (leafroller moths) - Lobesia botrana Den. et Schiff.; Erebidae (Macromoths) - Arctia villica L.; Geometridae (geometer moths) - Boarmia gemmaria Brahm., Idaea degeneraria Hubner; Papilionidae (Swallowtail butterflies) - Iphiclides podalirius L.; Noctuidae (cutworms) - Helicoverpa obsolete Hbr., Acontia trabealis Scopoli; Tettigoniidae (bush crickets) - Isophya taurica Br., Poeciliman sp.; Gryllidae (true crickets) - Oecanthus pellucens Scopoli; Thripidae (thrips) - Thrips tabaci Lind., Drepanothrips reuteri Uzel.; Phylloxeridae (phylloxera) - Viteus vitifolii Fitch.; Aphididae (aphids) - Aphis sp.; Coccidae (soft scales) - Parthenolecanium corni, Pulvinaria vitis L.; Cicadellidae (leafhopper) - Cicadella viridis L., Arboridia kakogawana Mats., Synophropsis lauri Horv.; Membracidae (treehopper) - Ceresa bubalus F.; Cixiidae Pentastiridius obscures Sign.; Issidae - Agalmatium bilobum F.; Pseudococcidae (mealybugs) - Pseudococcus citri Risso; Pentatomidae (shield bugs) - Dolycoris baccarum L., Coreus acuteangulatus Goeze, Eurydema sp., Nezara viridula L.; Miridae (leaf bugs) Lygus pratensis L.

Leafhoppers, leafroller moths, burnet moths, metallic wood-boring beetles and weevils were the most wide-spread grape pests among the study phytophagous insects. The majority of them are polyphages associated with vegetation growing between rows and in adjacent cenoces rather than with grapevine. Of such species, Iphiclides podalirius has been recorded in the Appendix of the Red Book of Russia and in the Red Book of Ukraine, which reflects the situation caused by increased recreation load, reduced natural areas of trees and bushes and application of pesticides. The population numbers of this insect can be restored by various methods, including conservation and renovation of natural sites covered by wild-growing Rosaceae bushes. Natural stations adjacent to vineyards and responsible for the "mosaic" pattern of the agrolandscape of the South Coast of the Crimea are exactly such patches.

The study predatory mites were represented by as many as 19 species of 10 families: Stigmaeidae - Zetzelia mali Ewing.; Trombidiidae (red velvet mites) - Trombidium sp.; 
Cunaxidae - Cunaxoides sp.; Bdellidae - Cyta sp.; Anystidae - Anystis sp.; Acaridae Acarus sp.; Pronematidae - Pronematus rapidus Kuzn.; Tydeidae - Tydeus caudatus Duges, T. californicus Banks; Tarsonemidae - Tarsonemus setifer Ewing.; Phytoseiidae Typhlodromus cotoneastri Wainst., Galendromus occidentalis Nesbitt., Phytoseius plumifer Can. et Fanz., Kampimodromus aberrans Oud., Euseius finlandicus Oud., Amblyseius marginatus Wainst., Paraseiulus soleiger Ribaga, Bawus subsoleiger Wainst., Anthoseius intercalaris Livsch. et Kuzn.

Among the study predatory insects, 20 species of 13 families were identified: Coccinellidae (lady bugs) - Coccinella septempunctata L., Adalia bipunctata L., Harmonia axyridis Pall., Thea (=Psyllobora) vigintiduopunctata L., Stethorus punctillum L.; Cantaridae (soldier beetles) - Rhagonycha fulva Scop., Rh. livida L.; Staphylinidae (rove beetles) - Olygota sp.; Chrysopidae (green lacewings) - Nineta flava Scop., Chrysopa flavifrons Br.; Hemerobiidae (brown lacewings) - Sympherobius pigmaeus Ramb; Cecidomyiidae (gall midges) - Arthrocnodax sp.; Chamaemyiidae (acalyptrate flies) Leucopis sp.; Thripidae (thrips) - Scolothrips acariphagus L.; Aeolothripidae - Aeolothrips fasciatus L.; Raphidiidae (snakeflies) - Raphidia sp.; Mantidae (malcolm gardiners) Mantis religiosa L.; Anthocoridae (minute pirate bugs) - Orius niger Wolff.; Eurytomidae - Euritoma verticillata F.; Forticulidae (earwigs) - Forficula sp.

Thus, the studied industrial vineyards are characterized by a significant species variety of arthropods, including predatory fauna. The biotic index, which characterizes the ratio of the number of species of predatory arthropods to the number of species of phytophages, was $1: 1,2$.

Our long-term research indicates that, subject to nonuse of pesticides, self-regulation of garden spider mite population numbers can be restored in commercial vineyards by employing the socalled "outskirts effect". Cancellation of chemicals against phytophages on the outskirts of a vineyard with an area of 1 ha over 2006-2011 benefited migration of predatory species of mites and other insects from adjacent natural biotopes, and, as a result, their population numbers increased and reservations on the outlying sites became established. The third year of nonuse of pesticides saw invasion of the predatory insects Arthrocnodax sp. and Orius niger L. and the predatory mites Stigmaeidae to the vineyard and their establishment on the outlying sites. In the forth year, population numbers of the predatory insects and mites increased throughout the vineyard, even when pesticides were applied. Following five years of nonuse of pesticides, the proportion of the predatory mites in the structure of the acarocomplex increased from 0.3 до $12.5 \%$ (Stigmaeidae) and from 1.7 to $19.6 \%$ (Phytoseiidae) while the biotic index grew from 1:47 to 1:2, with a fivefold decrease in the highest population numbers of the major phytophage at the peak of the population's actiivity.

Thus, reservations of a useful biota established on a part of a vineyard favored stablilization of the acarocomplex and formation of a self-regulated system approximating to natural cenoses whose typical feature is lack of mass development of a phytophage. Species diversity of the predators throughout the vineyard was also enriched.

In our study, species directly associated with the grape plant were, for the major part, phytophagous mites as well as predatory species of mites and other insects involved with them in trophic relations. These were phytophages of the families Tetranychidae, Tenuipalpidae, Thripidae, Heliozelidae, Pseudococcidae, Cicadellidae, Coccidae, Eryophyidae and their natural predators Phytoseiidae, Stigmaeidae, Tydeidae, Thripidae (Scolothrips acariphagus Jach.), Coccinellidae, Staphylinidae, Cecidomyiidae, Trombidiidae, Anthocoridae. Among them there were more permanent species under conditions of nonuse of pesticides (organic system) versus in comparison with conditions of pesticides were applied for pest control (traditional system). Phytophages accounted for the major proportion of the acarocomplex in both variants of our study $(80-85 \%)$. 
Intense use of pesticides is detrimental to predatory species and reduces biodiversity of those interrelated with a major phytophage since its population also becomes diminished. The two variants of our experiment showed a high species similarity of the study acarocomplexes $\left(\mathrm{K}_{\mathrm{j}}=0,53\right)$, though species diversity of mites and other insects associated with the grape plant was significantly higher without pesticides (organic system) versus traditional protection (Table 1). To be mentioned is that Berger-Parker dominance index was higher in the traditional variant, indicating an increased dominance of one species (garden spider mite) versus the organic system.

The work was partially done as part of the implementation of state assignment No. 0833-2019-0022.

Table1. Species diversity of the acaroentomocomplex under different conditions of viticulture.

\begin{tabular}{|c|c|c|c|c|c|}
\hline \multirow{2}{*}{$\begin{array}{c}\text { Variants } \\
\text { of pest control }\end{array}$} & \multicolumn{5}{|c|}{ Biodiversity indexes } \\
\cline { 2 - 6 } & $\begin{array}{c}\text { Shannon } \\
\text { species } \\
\text { diversity } \\
\text { index, } \mathbf{H}\end{array}$ & $\begin{array}{c}\text { Berger- } \\
\text { Parker } \\
\text { dominance } \\
\text { index, } \mathbf{d}\end{array}$ & $\begin{array}{c}\text { Margalef species } \\
\text { richness index, } \\
\text { Dmg }\end{array}$ & $\mathbf{K}_{\mathbf{j}}$ & $\begin{array}{c}\mathbf{t}_{\mathbf{H}}, \\
\mathbf{p} \leq \mathbf{0 . 0 5}\end{array}$ \\
\hline Traditional & 1.3 & 0.6 & 1.4 & \multirow{2}{*}{0.53} & 4.64 \\
\hline $\begin{array}{c}\text { Without } \\
\text { pesticides } \\
\text { (organic) }\end{array}$ & 1.6 & 0.5 & 2.0 & & \\
\hline
\end{tabular}

\section{Conclusions}

The acaroentomocomplex fauna of the "mosaic" agrolandscape of the South Coast of the Crimea was studied, and a considerable diversity of the taxonomical composition was revealed, with the dominance of predatory species in mites.

Implementation of organic viticulture in the Crimea, particularly on the South Coast of the Peninsula, with its special nature-conservative importance, will be beneficial for conservation and enhancement of species and landscape biodiversity of agrocenoses. Migrating ability of autochthonous predatory species of mites and other insects from natural territories covered with wild-growing trees, bushes and grasses and adjacent to vineyards allows to use them for pest control under conditions of reduced antropogenic load.

The data obtained indicates that natural mechanisms for self-regulation of population numbers of phytophagous mites can be relied on in technology of organic viticulture on the South Coast of the Crimea. Well-balanced trophic relations "phytophage - predator" should be pursued by a sustainable agroecosystem. In turn, phytosanitary measures should not lead to total elimination of a phytophage whose abundances should be maintained at an economically negligible level, in order to conserve and enhance reservations of a useful biota and the total biodiversity of an arocenosis.

At present, three enterprises relying on organic viticulture operate in different zones off the Crimea, and the legislative support of organic production in Russia opens prospects for more organic vineyards in the Peninsula.

\section{References}

1. D. Madge, Organic Viticulture: an Australian Manual (Department of Primary Industries, Victoria, 2005) 
2. Production guide for organic grapes 224 (NYS IPM, 2014)

3. H. Willer, J. Lernoud, Organic Viticulture Worldwide (Research Institute of Organic Agriculture (FiBL), Bonn/Frick, 2015) https://www.organicworld.net/yearbook/yearbook2015.html

4. H. Willer, J. Lernoud, L. Kilcher, The World of Organic Agriculture (Statistics and Emerging Trends, FiBL, Frick, 2013) http://www.organic-world.net/yearbook2013.html

5. H. Willer, J. Lernoud, L. Kemper, The World of Organic Agriculture (Research Institute of Organic Agriculture (FiBL), Frick and Bonn, 2019) https://shop.fibl.org/CHen/mwdownloads/download/link/id/1202/?ref=1

6. P. Coll, E. Le Cadre, E. Blanchart Philippe, H. Cécile Villenave, Applied Soil Ecology 50, 37-44.19 (2011)

7. A. Häseli, Protection of Vines Against the Main Diseases and Pests in Ecological Viticulture (NCO Bioinstitut, FiBL, Czech Republic, 2012)

8. A. Udomwech, A. Jai-Aree, S. Srisuantang, Kasetsart Journal of Social Sciences (2018) https://doi.org/10.1016/j.kjss.2018.02.01023.

9. C.O. Ehi-Eromosele, O.C. Nwinyi, O.O. Ajan, Weed and Pest Control, Chapter 5: Integrated Pest Management (Croatia, 2013) DOI: $10.5772 / 54476$

10. M. Retallack, L. Thomson, M. Keller, BIO Web of Conf. 15, 01004 (2019) https://doi.org/10.1051/bioconf/20191501004

11. U. Myga-Piątek, O. Rahmonov, Miscellanea Geographica 22(2) (2018) https://doi.org/10.2478/mgrsd-2018-0009

12. N.R. Haddaway, C. Brown, J. Eales, Environmental Evidence 7, 14 (2018)

13. C. Duso, S. Kreiter, M.-S. Tixier, Proceedings of the 12th International Congress, 399407 (2010) 